\title{
Use of the Rmocol Waste in Fiber Reinforced Concrete
}

\author{
Kartik Sharma, Deepika Sharma, Kongan Aryan, A.K Gupta
}

\begin{abstract}
Different types of wastes generated in today's world causes great harm to environment, resulting mainly in air, water and soil pollution. In civil engineering concrete plays a vital role in construction purposes. Keeping in mind the effects of global warming and air pollution Thermocol which when treated as a waste creates a lot of trouble when it is burned releases poisonous gases causing respiratory problems causing to death. Thermocol when buried makes the soil infertile and thus cause great harm to environment hence reducing the crop production. Thermocol is a pre expanded closed cell foam of polystyrene beats. It gives non-hydroscopic odorless rigid closed cell. So we can combined it with concrete to make a fiber reinforced concrete and it can be mixed easily because of its property of light weight and dimensional stability. This concrete can offers thermal resisting property as taken from Thermocol which can be used in ceilings and walls and also due to sound proof nature it can be used in sound proof structures. This fiber reinforced concrete offers improve tensile strength and energy absorbing properties in addition with improved impact strength and fatigue strength which in uncommon in normal concrete.
\end{abstract}

\section{INTRODUCTION}

Concrete is a compound made of cement, sand with mixing of fine and course aggregates in a definite proportion with addition of water by following proper water cement ratio. Mainly concrete shows compressive properties and it contains only one tenth tensile strength of its compressive strength for providing adequate tensile strength in concrete structures normally, we use steel bars of different diameter size. In this study we deal with the compressive strength of the concrete with mixing of desired fiber waste so that what other properties we will get after adding of fiber waste and what affect does it creates on compressive strength of concrete and what is the scope of that concrete in construction purposes. Since we know many types of fiber waste are there in our environment some of them are glass fiber, synthetic fiber including plastic, nylon and Thermocol fibers, natural fibers including rice husk and jute fiber.

\section{LITERATURE REVIEW}

Parhihkar in 2011 investigated the properties of volcanic pumicelightweightconcreteusingtwosamplesonewith course

aggregates with natural fine aggregates and other with course aggregates and fine aggregates. After the result of compressive

Revised Version Manuscript Received on August 19, 2019.

Mr. Kartik Sharma, B. tech 2nd year students, Department of Civil Engineering, DTU, Delhi.

Ms. Deepika Sharma, B. tech 2nd year students, Department of Civil Engineering, DTU, Delhi.

Prof. Dr. Kongan Aryan, Department of Civil Engineering, Delhi Technological University, Formally Delhi College of Engineering, Delhi.

Prof. A.K Gupta, Department of Civil Engineering, Delhi Technological University, Formally Delhi College of Engineering, Delhi. strength, tensile strength and drying shrinkage the study concludes that the light weight concretemeetstherequirement of structural light weight concrete. Sivalingarao in 2013 studied on light weight aggregate concrete with natural pumice stone. M20 grade was used in that and result was came that more target mean strength was achieved by $20 \%$ replacement of naturalaggregates with pumicestoneand $1.5 \%$ offiber.

Also when $40 \%$ of pumice and $0.5 \%$ of fiber target mean strength of M20 was achieved. DjWantoroHardjito in 2004 investigated over the properties of fly ash based geopolymer concrete mainly dealing with compressive strength. Author concluded that the compressive strength of geopolymer concrete has no relation with age of concrete however curing in high temperature and long curing will give thehigher strength and above all water in the concrete mix plays an important role in strength.

Mohd. Mustafa in 2011 gave ecofriendly concrete by replacing OPC with fly ash. He concluded that this concrete can be better than normal concrete in aggressive climate and high temperature.Lloydin2010putefforts to make geopolymer based concrete and tests were done on large scale concluding the usage of the samein precast members also.

\section{APPLICATIONS}

By producing fiber reinforced concrete using Thermocol thermal and sound resistant properties increases hence can minimize Thermocol waste as well from environment. This concrete can be treated as light weight concrete and can provide desired structural integrity as well. This concrete is useful in road pavements, industrial footings, bridge decks, canals linings, explosive resistant structures, refractory linings, fabrication of pipes, boats, beams, stair case steps, roof panels, wall panels, manholecovers.

Moreover it can be used in industrial footings, sprayed concrete can also be termed as guniting, fire resistant structures, slender structures. Lastly can alsobe used in precast members and mortar making works. 


\section{MATERIAL REQUIRED AND MIXING DETAILS CEMENT \& RESULTS}

Chemical compound made of silica, lime, alumina, iron oxide, magnesia, and Sulphur. Good quality cement should feel smooth on hands when rubbed and must contains good binding property when mixed with water and otherconstituents.

\section{FINEAGGREGATES}

Sand passed through $4.75 \mathrm{~mm}$ sieve having specific gravity 2.63 adfinenessmodulus 2.94

\section{COURSE AGREGATES}

Aggregates used was passed through $12.5 \mathrm{~mm}$ and retained on $10 \mathrm{~mm}$ sieve.

\section{THERMOCOL}

aclosedcell foam, rigid, tough, having pre- expanded polyester beads figure 1 shows below.

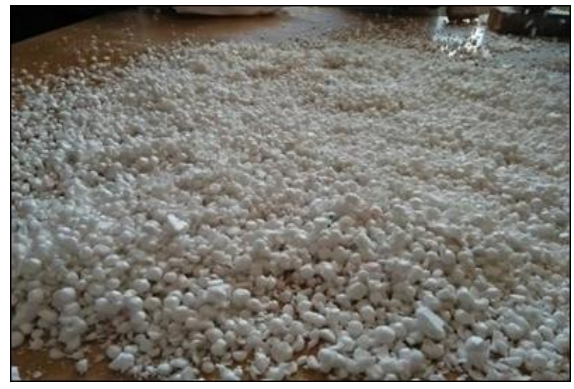

Figure no.1 Thermocol

Density range $15-30 \mathrm{~kg} / \mathrm{m}^{\wedge} 3$, compressive strength range $0.8-1.6 \mathrm{kn} / \mathrm{m}^{\wedge} 2$, tensile strength range $3-6 \mathrm{kn} / \mathrm{m}^{\wedge} 2$, melting point $100-200 \mathrm{C}$, thermal conductivity is low, sound absorption high and moistureabsorption low.

\section{CONCRETE MIX}

Various types of concrete grades classified from M5-M25 are considered as nominal mix and M30 and above are consideredas design mix. Cement, sand and aggregates (fine and course) can be taken by volume as well as by weight. Here in our study we took it by weight. We have used here M15 grade of nominal mix concrete by reference of IS 456-2000.

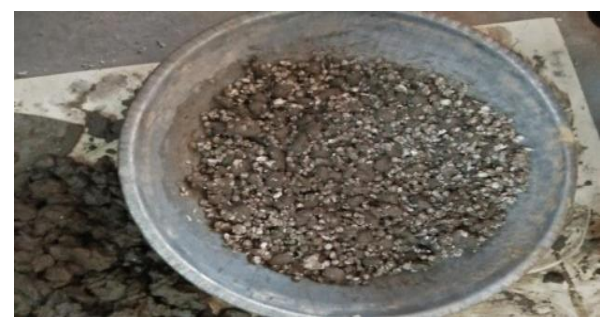

Figure no.2 Nominal Concrete Mix

\section{FACTORS AFFECTING CONCRETE MIX}

$\begin{array}{ll}> & \text { Compressive Strength } \\ > & \text { Workability } \\ > & \text { Durability } \\ & \text { Maximum Nominal Size of Aggregates }\end{array}$

\begin{tabular}{|l|l|}
\hline MIX & MIX DETAILS \\
\hline Ratio & $1: 2: 4$ \\
\hline Plain conc. & Cement: Fine agg. Coarse agg. \\
\hline
\end{tabular}

Table no.1 showing mix details

\section{TESTING METHODS AND RESULTS}

\section{WORKABILITY CHECK: -}

Can be done by performing 2 tests as follows.

\section{SLUMP TEST}

In this test we generally observe 3 types of slumps (true slump, shear slump and collapse slump). After testing in plain concrete a true slump was observed whereas after adding Thermocol a shear slump was seen.

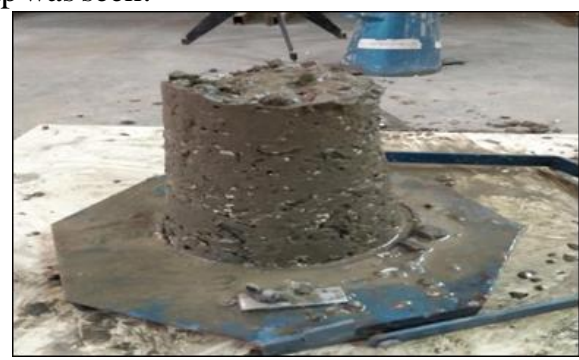

Figure no.3 True Slump

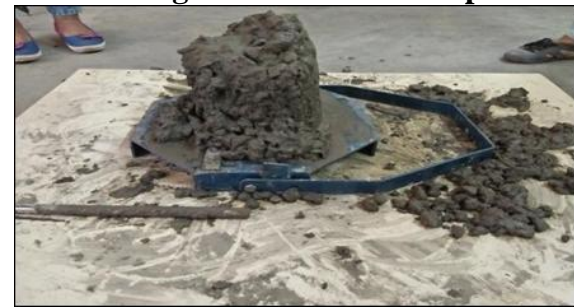

Figure no.4 Shear Slump

\section{COMPACTION FACTOR TEST}

Consistency of prepared concrete is observed by finding the ratio of weight of partially compacted concrete to weight of fully compacted concrete. Following details were observed from this test below.

\begin{tabular}{|c|c|c|}
\hline $\begin{array}{c}\text { Type of } \\
\text { concrete }\end{array}$ & $\begin{array}{c}\text { Wt. of } \\
\text { concrete } \\
\text { before } \\
\text { compaction }\end{array}$ & $\begin{array}{c}\text { Wt. of concrete after } \\
\text { compaction }\end{array}$ \\
\hline $\begin{array}{c}\text { Plain } \\
\text { concret } \\
\text { e }\end{array}$ & $11.32 \mathrm{~kg}$ & $11.36 \mathrm{~kg}$ \\
\hline $\begin{array}{c}1 \% \\
\text { FRC }\end{array}$ & $7.910 \mathrm{~kg}$ & $7.940 \mathrm{~kg}$ \\
\hline $2 \%$ FRC & $8.440 \mathrm{~kg}$ & $8.460 \mathrm{~kg}$ \\
\hline $3 \%$ FRC & $8.970 \mathrm{~kg}$ & $8.990 \mathrm{~kg}$ \\
\hline
\end{tabular}

Table no.2 showing compaction details. 


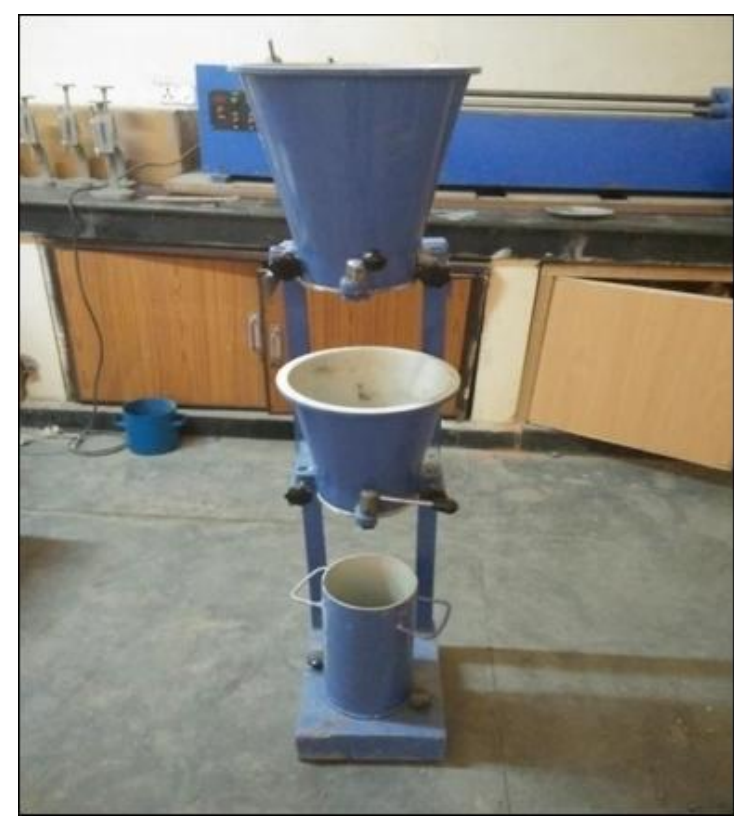

Figure no.5 Compaction Factor Apparatus.

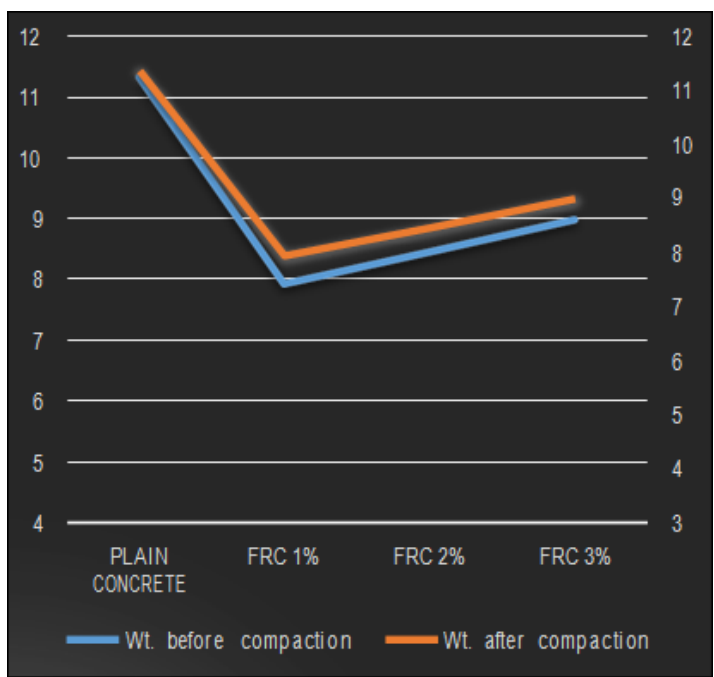

Graph no.1 Compaction factor

\section{COMPRESSIVE STRENGTH TEST}

This test gives the desired compressive strength of the cube made from fiber reinforced concrete cubes of (150x150x150) $\mathrm{mm}$ were designed and fully compacted on vibrating table and by tamping. Thermocol was addedin designed proportions.

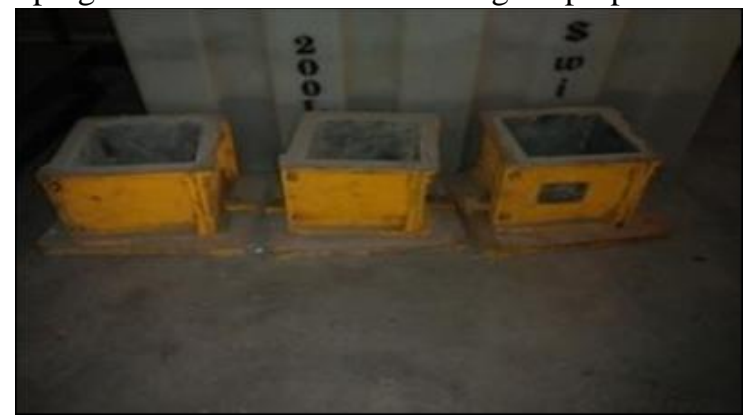

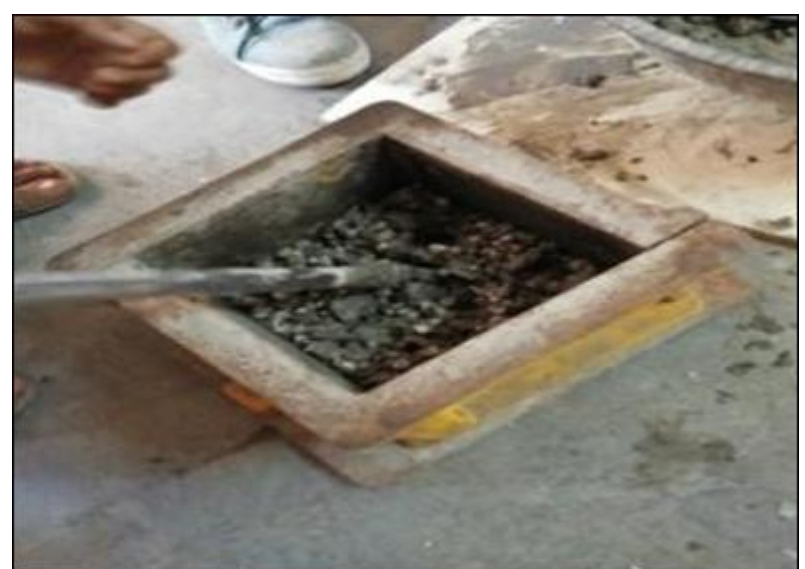

Figure no.6 (a) showing cube preparation (b) showing tamping

\begin{tabular}{|c|c|c|c|c|c|}
\hline $\begin{array}{l}\mathrm{S} . \\
\mathbf{O}\end{array}$ & $\begin{array}{l}\text { Mix Proport } \\
\text { Of Concrete }\end{array}$ & $\begin{array}{l}\text { Plain } \\
\text { Conc } \\
\text { rete }\end{array}$ & $\begin{array}{l}\text { Sam } \\
\text { ple } 1\end{array}$ & $\begin{array}{l}\text { Sam } \\
\text { ple 2 }\end{array}$ & Sample 3 \\
\hline 1 & \begin{tabular}{|l|} 
Fine \\
Aggregates
\end{tabular} & $2 \mathrm{~kg}$ & $2 \mathrm{~kg}$ & $2 \mathrm{~kg}$ & $2 \mathrm{~kg}$ \\
\hline 2 & \begin{tabular}{|l} 
Coarse \\
Aggregates
\end{tabular} & $4 \mathrm{~kg}$ & $4 \mathrm{~kg}$ & $4 \mathrm{~kg}$ & $4 \mathrm{~kg}$ \\
\hline 3 & Cement & $1 \mathrm{~kg}$ & $1 \mathrm{~kg}$ & $1 \mathrm{~kg}$ & $1 \mathrm{~kg}$ \\
\hline 4 & $\begin{array}{l}\text { Fibre } \\
\text { (Thermocol) }\end{array}$ & Nil & $\begin{array}{l}1 \%( \\
10 \mathrm{~g} \mathrm{~ms}\end{array}$ & $2 \%($ & $\begin{array}{l}\text { 3\%(30g } \\
\text { ms) }\end{array}$ \\
\hline
\end{tabular}

Tableno.3ShowingMixProportionDetails

\begin{tabular}{|c|c|c|c|c|c|}
\hline S.N & Age 0 & ffype 0 & fload & Cross- & Compressi \\
\hline O. & Cube & $\begin{array}{l}\text { Concre } \\
\text { te Cube }\end{array}$ & $\begin{array}{l}\text { Applie } \\
(\mathbf{k N})\end{array}$ & $\begin{array}{l}\text { d sectio } \\
\text { area } \\
\left(\mathbf{m m}^{\wedge}\right. \\
2)\end{array}$ & $\begin{array}{l}\text { nve Strength } \\
\left(\mathbf{N} / \mathbf{m m}^{\wedge} \mathbf{2}\right)\end{array}$ \\
\hline 1 & 28day & $\begin{array}{l}\text { Plain } \\
\text { Concre } \\
\text { te }\end{array}$ & 250 & 22500 & 11.11 \\
\hline 2 & $\begin{array}{l}28 d a y \\
s\end{array}$ & $\begin{array}{l}\text { Sample } \\
1\end{array}$ & 200 & 22500 & 8.89 \\
\hline 3 & $\begin{array}{l}28 d a y \\
\text { s }\end{array}$ & $\begin{array}{l}\text { Sample } \\
2\end{array}$ & 180 & 22500 & 8.00 \\
\hline 4 & $\begin{array}{l}28 d a y \\
s \\
\text { 2 }\end{array}$ & $\begin{array}{l}\text { Sample } \\
3\end{array}$ & 150 & 22500 & 6.67 \\
\hline
\end{tabular}

Table no.4 Showing Load and Compressive strength Details

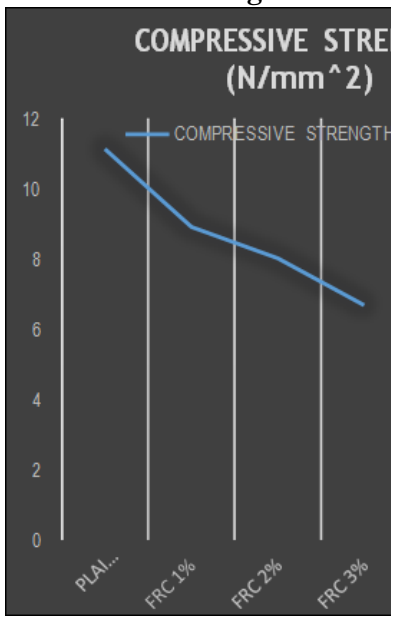

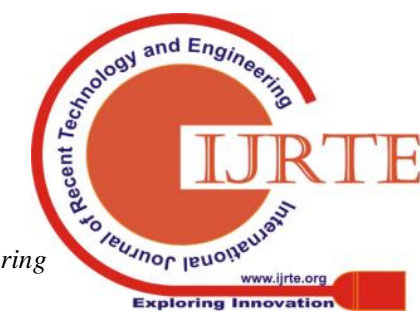




\section{USE OF THE RMOCOL WASTE IN FIBER REINFORCED CONCRETE}

\section{Graphno.2showingcompressivestrength}

The average 28 day strength of concrete sample is found to be $8.67 \mathrm{~N} / \mathrm{mm}^{\wedge} 2$. A decrease in compressive strength shown by gradual addition of Thermocol of $1 \%, 2 \%, \& 3 \%$.

\section{NON-DISTRUCTIVE TESTS}

Non-destructive parameters are tested by using ultrasonic pulse velocity test and rebound hammer test to determine the homogeneity of concrete as well as to detect the voids, cracks and segregation in compacted concrete and hence concluding the overall quality of concrete.

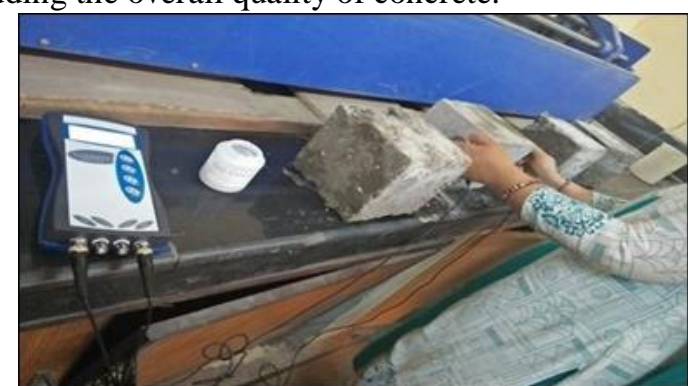

Figure no.7 Performing Pulse Velocity Test

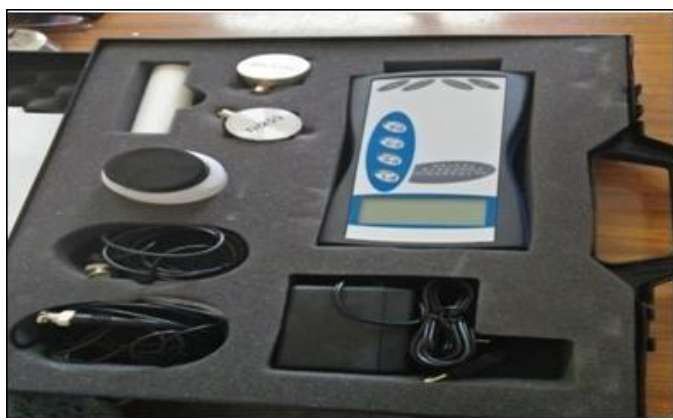

Figure no.8 ultrasonic pulse velocity Apparatus

\begin{tabular}{|l|l|l|l|l|}
\hline $\begin{array}{l}\text { S.N } \\
\text { o. }\end{array}$ & $\begin{array}{l}\text { TYPE OFDISTANC } \\
\text { CONCRE } \\
\text { TE }\end{array}$ & $\begin{array}{l}\text { TIME } \\
\text { Eec }) \\
(\mathrm{km})\end{array}$ & $\begin{array}{l}\text { IMPULSE } \\
\text { VELOCIT } \\
\text { Y } \\
(\mathrm{km} / \mathrm{sec})\end{array}$ \\
\hline 1 & $\begin{array}{l}\text { PLAIN } \\
\text { CONCRE } \\
\text { TE }\end{array}$ & $\mathbf{1 5 0}^{* 10^{\wedge}-6}$ & $\begin{array}{l}33.6 * 10 \\
\wedge-6\end{array}$ & 4.46 \\
\hline 2 & FRC 1\% & $150 * 10^{\wedge}-6$ & $\begin{array}{l}40.7 * 10 \\
\wedge\end{array}$ & 3.68 \\
\hline 3 & FRC 2\% & $150^{*} 10^{\wedge}-6$ & $\begin{array}{l}38.1 * 10 \\
\wedge-6\end{array}$ & 3.93 \\
\hline 4 & FRC 3\% & $150 * 10^{\wedge}-6$ & $\begin{array}{l}37.5 * 10 \\
\wedge\end{array}$ & 4 \\
\hline
\end{tabular}

Table no.5 showing impulse velocity details

For concrete quality grading impulse velocity above 4.5 is considered as excellent from 3.5-4.5, it is termed as good from 3-3.5 it is termed as medium and below 3 it is termed as bad.

The impulse velocity of plain concrete found to be excellent as it is above 4.5 and after comparing it with fiber reinforced concrete it is good. Most suitable FRB is of $3 \%$ Thermocol mixture having value 4 .

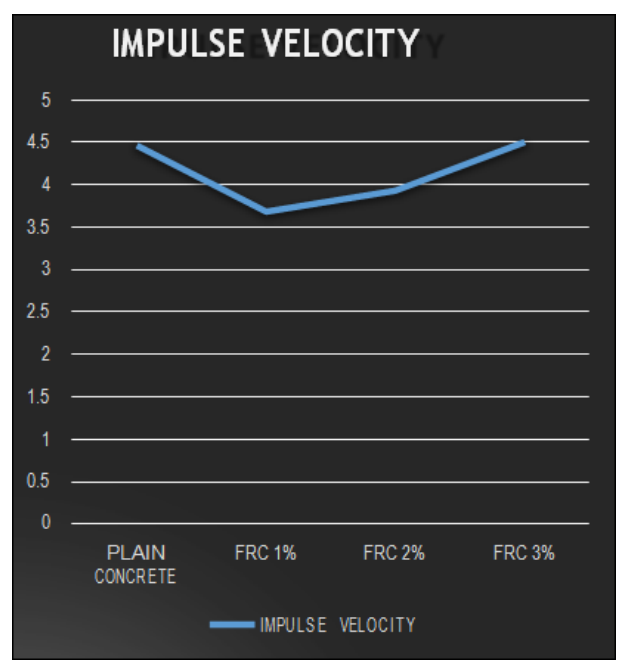

Graph no.3 showing Impulse Velocity

\section{REBOUND HAMMER TEST}

Suitable co-relations found between rebound index and compressive strength. Assessing the suitable uniformity of concrete and determining the quality of one element in relation toother.

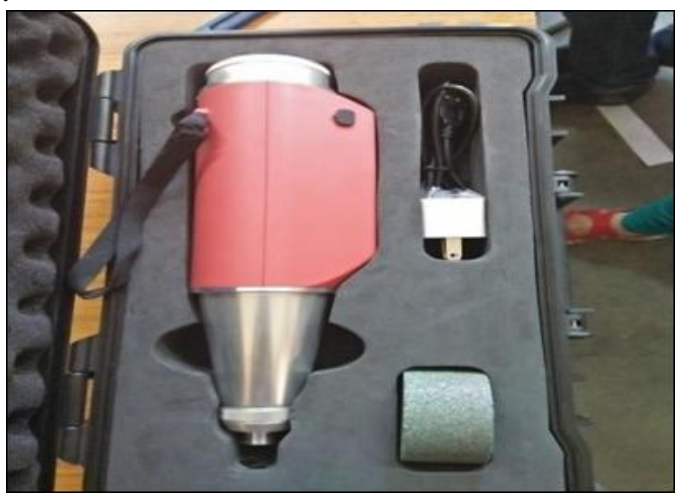

Figure no.9 Rebound Hammer Apparatus 
For testing normal weight concrete the impact energy required for rebound hammers is $2.25 \mathrm{Nm}$, for testing light weight concrete or impact sensitive parts of concrete it must be $0.75 \mathrm{Nm}$ and for testing mass concrete value must be $30 \mathrm{Nm}$

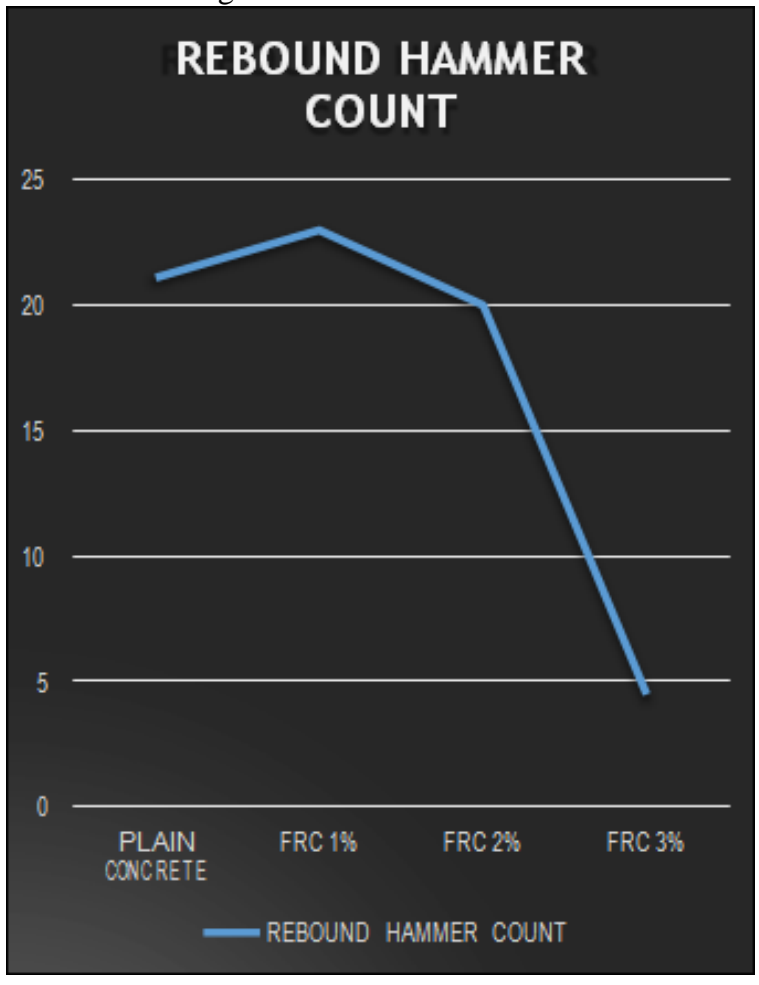

Graph no.4 showing Rebound Hammer Count

Rebound count decreases with increasing proportions of Thermocol $n$ concrete. It shows that the uniformity decreases and ultimately compressive strength decreases as compared to normal plain concrete.

\section{CONCLUSION AND DISCUSSIONS}

We observed that some of the isotropic strength properties added in fiber reinforced concrete with increased thermal resistance, impact strength, and energy absorbing characteristics. It cannot be concluded that the use of Thermocol based fiber reinforced concrete will overcome the use of conventional concrete but it can provide a suitable crack resistant structure and higher ductility. Above mentioned properties of FRC may be useful in some specified conditions where conventional concrete isless suitable. This can beanew approach in designing and utilization of waste material of Thermocol and to manage some of waste generating is today's environment thus can also be useful in managing economy.

\section{REFERENCES}

1. 'Chapter 5 natural fiber reinforced concrete' of "textbook of fibrous and composite materials for civil engineering applications" by F.P Torgal \& S. Jalali published in 2011.

2. Chapter 7 of Developments of formulations and reinforcements in concrete by S. Mindess in 2008.

3. Fibrous and composite materials of civil engineering applications by K. Raoufi \& J. Weiss in 2011.

4. Sustainability of fiber composite concrete construction by O. Kayali in sustainability of construction materials (2nd edition) in 2016

5. Enhancement of the strength of conventional concrete by using nylon fiber by jaya saxena \& prof. Anil Saxena.
6. IS 456-2000 "Indian code for recommended plain and reinforced concrete". (Fourth revision).

7. IS 10262-1982 "Indian code for recommended guidelines for concrete mix design".

8. IS 516-1959 "Indian code for method of tests of concrete".

9. Mix design of fiber reinforced concrete (FRC) using slag \& steel fiber by Mr. Nikhil A. Gadge, prof. S.S Vidhale.

10. Ramakrishna. V (1987), "Materials and properties of fiber reinforced concrete" - Proceedings of the international symposium on FRC, Madras.

11. Fiber Reinforced Concrete http://www.latech.edu/guice/ReinforcedCon/Papers/perk ins.htm, January 29, 2001.

12. Textbook of "structural mechanics" by A.K Upadhaya first edition, July 2010-11.

13. Textbook of building construction Dr. S.P bindra (B.se,

14. B.E. in civil, M.E.(hons.), Ph.D. (UK)) And S.P Arora (B.E.\&M.E. from, Roorkee; MIRC, MIE (INDIA) ).

15. R.N Swamy "Testing and test methods of fiber cement composites" published 1978.

16. Aron Bentur and Sydney Mindess "Fiber reinforced cementitious composites" 2nd edition, 2007.

17. wrd.mpeprocurement.gov.in, cafetinnova.org, wiki.answers.com (internet source).

18. Guidance from Prof.Suman Mann (concrete technology expert) Kasturba institute of technology, pitampura, Delhi. 